and China, and he was already well known in photographic circles when, at the age of forty years, he joined Capt. Scott's last expedition. Here he mixed, possibly for the first time, with a number of men of science who, aware of his reputation, besieged him with special work on their behalf. His reaction to these requests was typical of the man. His kindness of heart would urge him to take exactly what was required of him, though his artistic sense would rebel against banal subjects that he was set to record. Nevertheless, he would take hours endeavouring to make a real picture from such unpromising material as a cliff face or stratification in a glacier.

Ponting always maintained that he was not a photographer but a camera artist, and this was truer of him than it could be of most who claim the latter name. He was a merciless critic of his own work, and would destroy all negatives which did not come up to the high standard he set himself. The noise of breaking glass in his dark room was not uncommon, and usually heralded his reappearance, laden with cameras once more, to go and take his subject over again. His cinematograph work was at that time in advance of that done by any previous film traveller. The world has only seen a small fraction of the footage taken by him, and he probably spent more actual time with his cinema than with his still camera. Here again, however, his work could not be called scientific in the purest sense, largely because the artist in him quarrelled with the man of science, and usually won.

Although Ponting was devoted to his work, and had few interests outside it, he recognised its commercial value, and this brought him into touch with the financiers of the film world, a milieu unsuited to his temperament and one in which his experience was not always happy. On visiting him at his London flat, one was sure to find him either in the depths of despair at some plans gone awry or full of enthusiasm at some new venture, usually connected with the exhibition of the Scott films.

Ponting had a simple and generous mind and he suffered very deeply at the loss of Scott and Wilson. $\mathrm{He}$ devoted himself for many years to the task of perpetuating their memory through his still pictures and his films. Those who have enjoyed them will acknowledge his success, and many of his camera studies will endure for all time as perfect examples of his art.

\section{Prof. O. D. Chwolson}

Prof. O. D. Chwolson, of the University of Leningrad, who died on May 11, 1934, is well known as the author of a textbook of physies, originally published in Russian and later translated into German, French and Spanish. It was one of the first textbooks written for high-school students and enjoys a deservedly high reputation. Its success has been due to the masterful treatment of the subjects by a highly gifted lecturer and teacher. The first four volumes were written by Prof. Chwolson himself; the last volume consists of ehapters written at Prof. Chwolson's request, and on the lines he indicated, by specialists, his pupils, in various branches of modern physies.

Prof. O. D. Chwolson was born in 1852 as a son of a well-known Hebrew scholar. He matriculated at the age of seventeen and took up his studies at the University of St. Petersburg. He graduated with honours in 1873. The next year he spent in research at Leipzig, but in 1875 he was back again in Russia. He took his 'master's' degree in 1876 and his doctorate in 1880. His early research work dealt with various questions of electricity and magnetism, as well as with actinometry. The work on actinometry was preceded by some investigations on the mathematical theory of conduction of heat, and the result was an actinometer which for a long time served as a standard type instrument in Russian meteorological observatories.

After 1876 all Prof. Chwolson's work was devoted to teaching, and among the numerous students of fifty years, there was scarcely one who was not fascinated by his lectures. He knew how to address the beginners as well as advanced students, his lectures being carefully prepared.

Prof. Chwolson took an active part in the teaching of physies in secondary schools and especially in the training of teachers. In 1907, he organised a committee for the investigation of the provision for physical laboratories and demonstration rooms in secondary schools, and in 1913, a meeting of teachers in physics, chemistry and geophysics in secondary schools. He was elected permanent honorary president of the section of teaching of the Russian Physical and Chemical Society.

The great gift of popularisation of scientific achievements added considerably to Prof. Chwolson's activities. Most of his lectures were afterwards published and make very pleasant reading. His books appeal to the average man just as well as to the scientific worker. Only a few years ago Prof. Chwolson published a book on "Modern Physics", dealing with the latest achievements in physics. Some 300,000 copies were published, so great was the demand for it in the U.S.S.R.

It is scarcely possible in a brief obituary notice to give an appreciation of Chwolson the man, modest, hard-working and with true enthusiasm for scientifie knowledge. The world has benefited from his philosophical conceptions and from his ideas about the influence of science on social life. Several generations of physicists, not only in the U.S.S.R. but also in other countries, will keep his name in grateful remembrance.

\section{WE regret to announce the following deaths :}

Dr. James Clark, emeritus rector of Kilmarnock Academy and formerly principal of the Central Technical Schools for Cornwall, Truro, on February 19.

Dr. Axel Wallén, director of the State Meteorological Hydrographic Institute of Sweden and presi. dent of the Meteorology Association of the International Union of Geodesy and Geophysics, on February 23. 